\title{
INTERNAL TIDES OVER THE SANTOS PLATEAU
}

\section{E.G. Morozov}

Shirshov Institute of Oceanology, Russian Academy of Sciences, 36, Nahimovskiy prospekt, Moscow, 117997, Russia,e-mail:egmorozov@mail.ru

Submitted 02.02.2018, Accepted 26.04.2018

\begin{abstract}
We analyze internal tides over the Santos Plateau in the South Atlantic. The study is based on the measurements of temperature and currents on the line of moorings normal to the South America coast in the latitudinal band between $28^{\circ} \mathrm{S}$ and $31^{\circ} \mathrm{S}$. The moorings were deployed at distances between 25 and $888 \mathrm{~km}$ (from the $500 \mathrm{~m}$ isobath) Southeast of the continental slope. The instruments were set at $900 \mathrm{~m}$. Numerical modeling revealed the properties of internal tides (amplitudes, wavelength, and decay of amplitudes) along the line of their propagation from the continental slope. The amplitudes of internal tide decrease from the continental slope in the direction to the Vema Channel from $36 \mathrm{~m}$ to $15 \mathrm{~m}$. The densities of the energy of tidal internal waves were calculated from the semidiurnal tidal components of current and temperature time series taking into account the vertical gradients of temperature and the Brunt-Väisälä frequency. Decay of the energy of internal tide occurs according to an inverse power law. Numerical modeling of the generation and propagation of internal tides reveals that beams of internal tides are formed near the continental slope. The energy decay based on modeling is similar to the measured data.
\end{abstract}

Keywords: internal tide, moorings, Santos Plateau, Brazil Basin, numerical modeling, energy decay

\section{Introduction}

The region of the Santos Plateau in the South Atlantic is interesting in the sense of Antarctic Bottom Water (AABW) spreading to the north. The dominating transport of AABW occurs through the Vema Channel (Morozov, 2008). Part of AABW transport occurs over the Santos Plateau (Speer and Zenk, 1993). The steady Northward flow of $\mathrm{AABW}$ is influenced by strong internal waves generated in the region. It was shown in (Morozov 1995) that internal tides in the South Atlantic are very intense. Internal tides are generated by the interaction of the strong barotropic tide with the slopes of bottom topography. When flowing over the continental slope of South America and the slopes of the Mid-Atlantic Ridge tidal currents obtain a significant vertical component. This leads to the generation of strong internal tides of high amplitude that propagate from the slopes of bottom topography to the open ocean. In this study we analyze the data of measurements on moorings in the region and use the Vlasenko numerical model to get a general concept of the processes of internal tide generation and propagation. We also estimate the decay of internal tide energy in the course of internal wave propagation from the continental slope of South America. Previous measurements of internal tides in the region are reported in several publications. Pereira and Castro (2007) report about 


\section{Е.Г. Морозов}

the measurements of the internal tides in 2001 near Brazil in the region of Cabo Frio $\left(23^{\circ} \mathrm{S}, 42^{\circ} \mathrm{W}\right)$. According to their estimates, the amplitudes of the semidiurnal internal tides reached $30 \mathrm{~m}$.

\section{Mooring data}

In 1991-1992, moored experiments have been conducted in the Brazil Basin over the Santos Plateau in the region between $28-31^{\circ} \mathrm{S}$. Several moorings were deployed in a line: WOCE ACM 12 moorings at $27^{\circ} 54^{\prime} \mathrm{S}, 46^{\circ} 42^{\prime} \mathrm{W}, 27^{\circ} 59^{\prime} \mathrm{S}, 46^{\circ} 20^{\prime} \mathrm{W}$, $28^{\circ} 16^{\prime} \mathrm{S}, 45^{\circ} 13^{\prime} \mathrm{W}, 39^{\circ} 46^{\prime} \mathrm{S}, 31^{\circ} 12^{\prime} \mathrm{W}$; and WOCE ACM 3 moorings at $28^{\circ} 28^{\prime} \mathrm{S}$, $44^{\circ} 28^{\prime} \mathrm{W}, 2^{\circ} 03^{\prime} \mathrm{S}, 43^{\circ} 29^{\prime} \mathrm{W}, 30^{\circ} 05^{\prime} \mathrm{S}, 41^{\circ} 44^{\prime} \mathrm{W}$. These moorings were part of the experiments ACM-3 and ACM-12 (Deep Ocean) of the WOCE Program. Locations of moorings and bottom topography are shown in Fig. 1. The experiments were dedicated to the investigation of the bottom circulation in the Atlantic. The experiments were organized by the scientists from WHOI (USA) (ACM 3) and Meereskunde (Germany) (ACM 12). We used the temperature and velocity measurements in the layer 800$1000 \mathrm{~m}$ to analyze the variations in internal tides over the line of moorings from the continental slope.

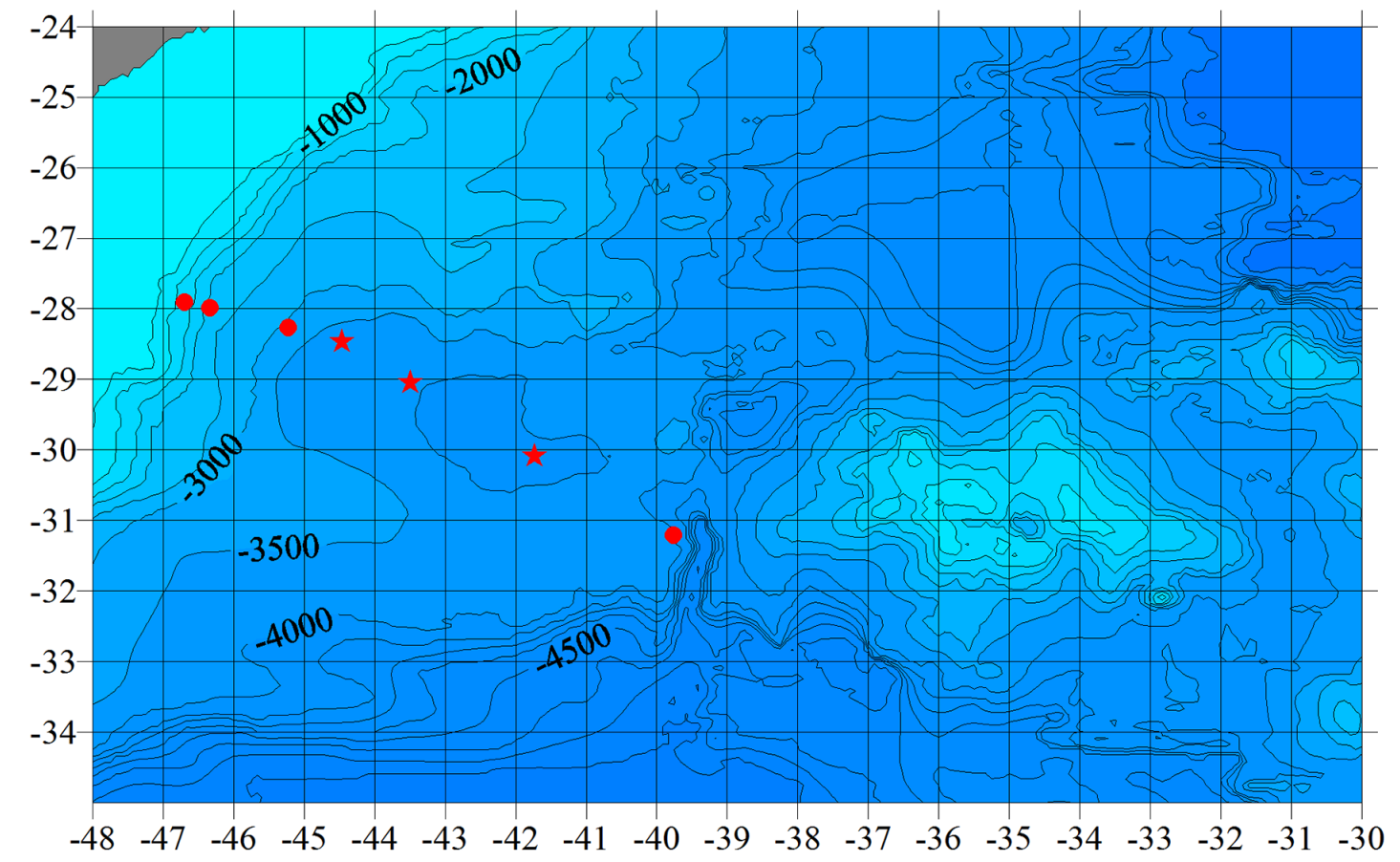

Fig. 1. Bottom topography (meters) in the South Atlantic East of Brazil and locations of moorings of the WOCE ACM-3 and ACM-12 experiments. Depth contour lines are shown with an interval of $500 \mathrm{~m}$. Locations of the ACM-3 moorings are shown with red circles, the ACM-12 moorings are shown with red stars. Land is shown with gray color.

The semidiurnal internal tide can easily be distinguished in all time series of water temperature (even visually). For example, the amplitude of temperature fluctuations at a depth of $914 \mathrm{~m}$ on mooring $1086\left(30^{\circ} 05^{\prime} \mathrm{S}, 41^{\circ} 44^{\prime} \mathrm{W}\right)$ is $0.15-0.20^{\circ} \mathrm{C}$. Recalculation 
of temperature fluctuations to the vertical displacements assuming that the vertical temperature gradient is $0.008-0.010^{\circ} \mathrm{C} / \mathrm{m}$ yields an amplitude of the waves equal to 15-25 m. The amplitudes of internal tide decrease from the continental slope in the direction to the Vema Channel from $35 \mathrm{~m}$ to $18 \mathrm{~m}$. The calculations of the spectral densities of the fluctuations of the temperature and currents based on the data of the measurements demonstrate the existence of a clearly manifested peak in the semidiurnal period that corresponds to the $\mathrm{M}_{2}$ tidal period. An example of such calculations of spectral function based on the temperature measurements on mooring 1086 (914 m depth) is shown in Fig. 2.

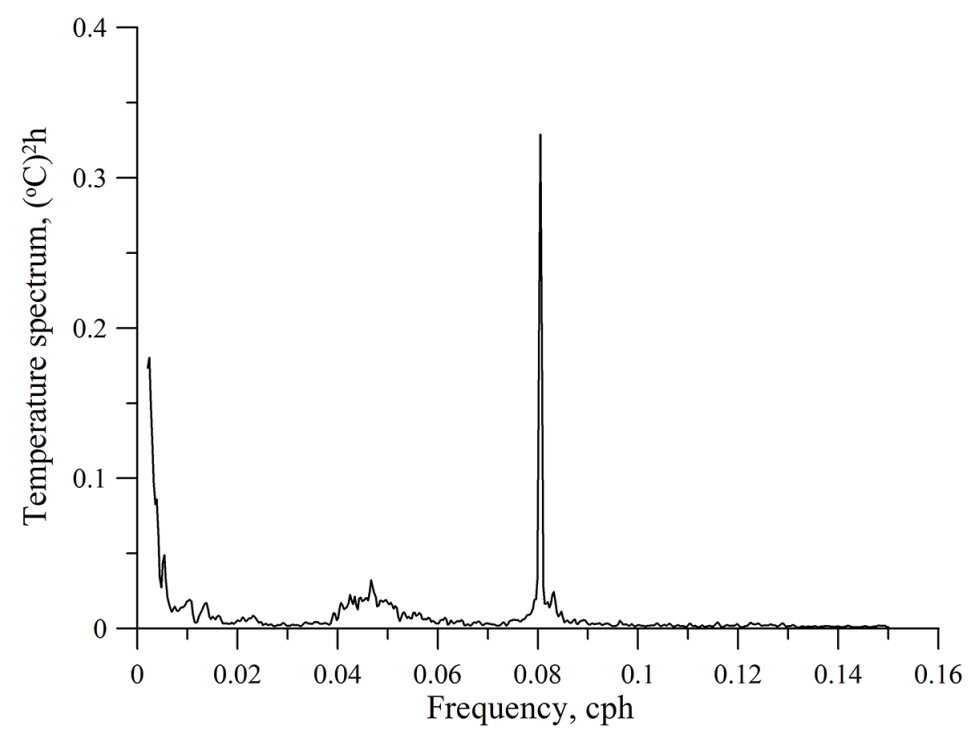

Fig. 2. Spectrum of temperature fluctuations (ACM-3). Measurements at $914 \mathrm{~m}$ on mooring 1086 at $30^{\circ} 05^{\prime} \mathrm{S}, 41^{\circ} 44^{\prime} \mathrm{W}$.

\section{Modeling of internal tides}

We analyze the wave propagation using the numerical model developed by V. Vlasenko (Vlasenko 1992; Morozov, Vlasenko, 1996; Vlasenko et al., 2005). Numerical modeling allows us to obtain internal wave properties in a wide range of oceanic conditions: stratification, parameters of the tide, bottom topography, and also to investigate separately any factor influencing the properties of internal waves, which is impossible in an oceanic field experiment.

The model is two-dimensional $(x, z)$. We analyze internal motions in a continuously stratified rotating ocean of variable depth. Then, internal waves are described by the following set of equations:

$$
\begin{aligned}
& \Omega_{t}+J(\Omega, \Psi)-f V_{z}=\frac{g \rho_{x}}{\rho_{0}}+K(x) \Omega_{x x}+K \Omega_{z z}+\left(K \Psi_{z z}\right)_{z} \\
& V_{t}+J(V, \Psi)+f \Psi_{z}=K(x) V_{x x}+\left(K V_{z}\right)_{z} \\
& \rho_{t}+J(\rho, \Psi)+\frac{\rho_{0} N^{2}(z)}{g} \Psi_{x}=R(x) \rho_{x x}+\left(R \rho_{z}\right)_{z}+\left(R \rho_{0_{z}}\right)_{z},
\end{aligned}
$$


where $\Psi$ is the stream function $\left(\Psi_{z}=u\right.$; $\left.\Psi_{x}=w\right), \Omega=\Psi_{x x}+\Psi_{z z}=w$ is the vorticity, $(U, V, W)$ is the velocity vector, $N$ is the Brunt-Väisälä frequency, $\rho$ is the density disturbance due to the wave motion, $\rho_{0}$ is the mean density, $f$ is the Coriolis parameter, $K, K(x), R$, and $R(x)$ are the vertical and horizontal coefficients of turbulent viscosity and mass diffusivity, $J$ is the Jacobian and $g$ is the acceleration due to gravity.

The model is two-dimensional, but we introduce the equation for the $V$-component of velocity normal to the $x, z$ plane to take rotation into account. However, the $V$-component is considered constant. We use the equation of density diffusion instead of the equations of heat and salt diffusion. The boundary conditions at the surface located at $z=0$ are:

$$
\rho=0, \Omega=0, \Psi=0 .
$$

We assume that the vertical motion is zero as well as the heat and salt transports through the surface are also zero.

At the bottom, no heat, salt, and mass transports exist:

$$
\text { at } z=-H(x): \partial \rho / \partial n=0, \Psi=\Psi_{0} \sin w \mathrm{t},
$$

where $w$ is the tidal frequency, $n$ denotes the unit vector normal to the bottom and $\Psi_{0}$ is the amplitude of the stream function determining the mass transport in a barotropic tidal current. The boundary condition for vorticity at the bottom is calculated from equation $\Omega=\Delta \Psi$ with the value of the $\Psi$ field calculated at the previous time step.

The perturbations of vorticity, stream function, and density are assumed zero at the vertical lateral boundaries located far from the bottom irregularities of the continental slope. We stop the calculations when the wave perturbations reach the lateral boundaries.

The calculations start from a state of zero motion while the isopycnals are horizontal; hence: at $t=0: \Omega=0, \rho=0, \Psi=0$.

A semi-implicit numerical scheme utilizes a rectangular grid with second order approximations of the spatial derivatives and first order approximations of the temporal derivatives in every temporal semi-layer. At each time step, the implicit system, which is a tri-diagonal matrix, is solved using standard techniques.

We model the following physical phenomenon. A long barotropic tidal wave propagates from the open ocean to the continental slope. The tidal currents flow over the slope and obtain a vertical component. Periodically oscillating vertical components with a tidal period displace isopycnals; thus a tidal internal wave is generated. As indicated above, the input parameters of the model are stratification, bottom topography, and stream function of the tidal current.

The input data to the model include: velocities of the barotropic tide, stratification, and bottom topography. Tidal velocities were calculated from the satellite data using the NASA database available at Oregon State University; the method is described by Egbert and Erofeeva (2002). Stratification of the ocean (unperturbed state) was taken from the CTD-data in this region (WOD13 2013). The bottom topography was specified from the ETOPO digital database (http://www.ngdc.noaa.gov/mgg/global/global.html). 
The domain for numerical simulations was $800 \mathrm{~km}$ long with a horizontal step of $1000 \mathrm{~m}$ and 34 vertical levels. The width of the shelf was specified as $100 \mathrm{~km}$. The time step was $8 \mathrm{~s}$. The coefficients of horizontal viscosity and density diffusion over the slope were specified at $250 \mathrm{~m}^{2} / \mathrm{s}$, and they gradually decreased to $200 \mathrm{~m}^{2} / \mathrm{s}$ over $100 \mathrm{~km}$. At greater distances they were specified constant. The corresponding vertical coefficients were $0.0001 \mathrm{~m}^{2} / \mathrm{s}$. The stream function amplitude (water transport) related to the barotropic tide forcing was specified equal to $260 \mathrm{~m}^{2} / \mathrm{s}$ at the bottom and zero at the ocean surface, which is consistent with the velocities of the barotropic tide far from the continental slope.

As a result of simulations we obtained a density section for the given tidal phase when the wave propagates opposite to the tidal currents, which cause intensification of the wave. The calculated density field after $10 \mathrm{M}_{2}$ periods is shown in Fig. 3. The figure clearly shows the formation of an internal wave propagating from the continental slope to the open ocean.

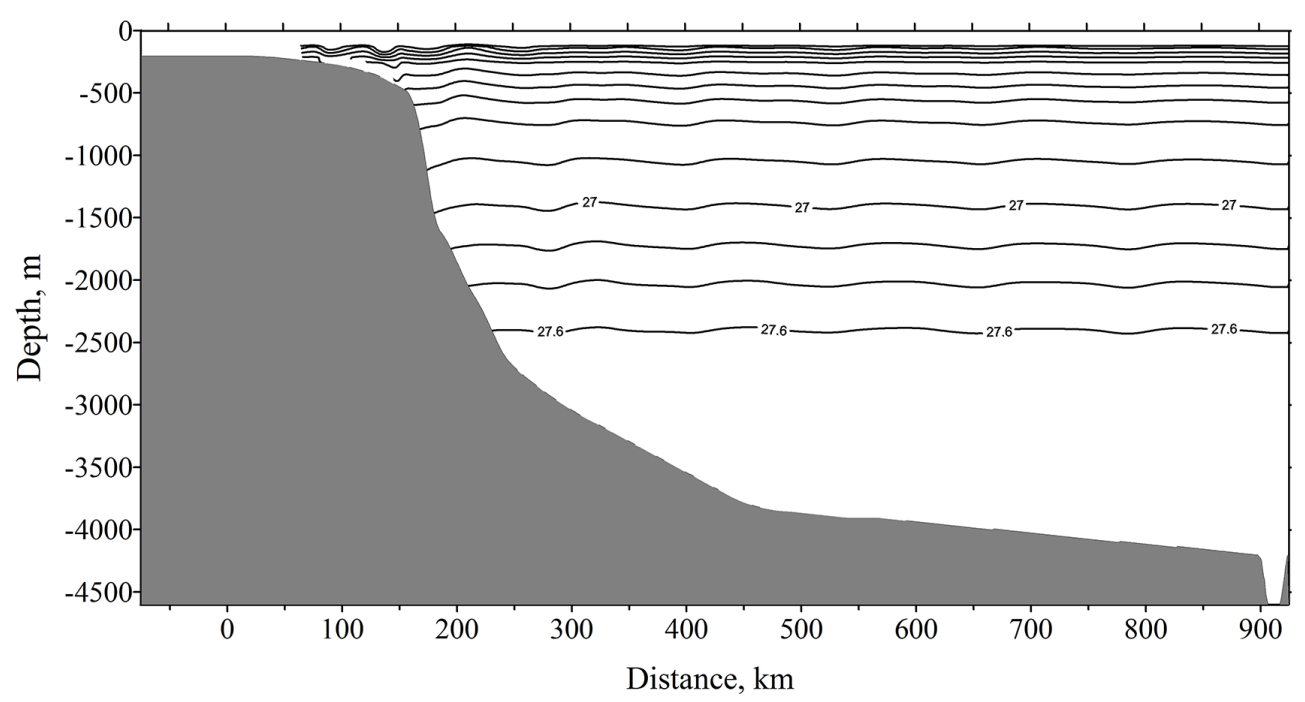

Fig. 3. Simulated density field over a section normal to the coast over the Santos Plateau after 10 tidal periods of calculation. The density of seawater at the surface was assumed equal to $1.02276 \mathrm{~g} / \mathrm{cm}^{3}$. Density contour lines are plotted with an interval of $0.0001 \mathrm{~g} / \mathrm{cm}^{3}$. Numerals 27 and 27.6 indicate isopycnals 1.0270 and $1.0276 \mathrm{~g} / \mathrm{cm}^{3}$.

The wavelength of the wave directed to the open ocean was close to $130 \mathrm{~km}$ over the slope increasing in the deep ocean up to $145 \mathrm{~km}$. The amplitudes of internal tides at the shelf break reached $50 \mathrm{~m}$. High amplitudes of internal tides are confirmed by moored measurements.

The velocity field is shown in Fig. 4. One can see beams of internal tides. The curve of the characteristic line is determined by the following equation.

$$
\frac{d z}{d x}= \pm\left(\frac{\omega^{2}-f^{2}}{N^{2}-\omega^{2}}\right)^{1 / 2}
$$




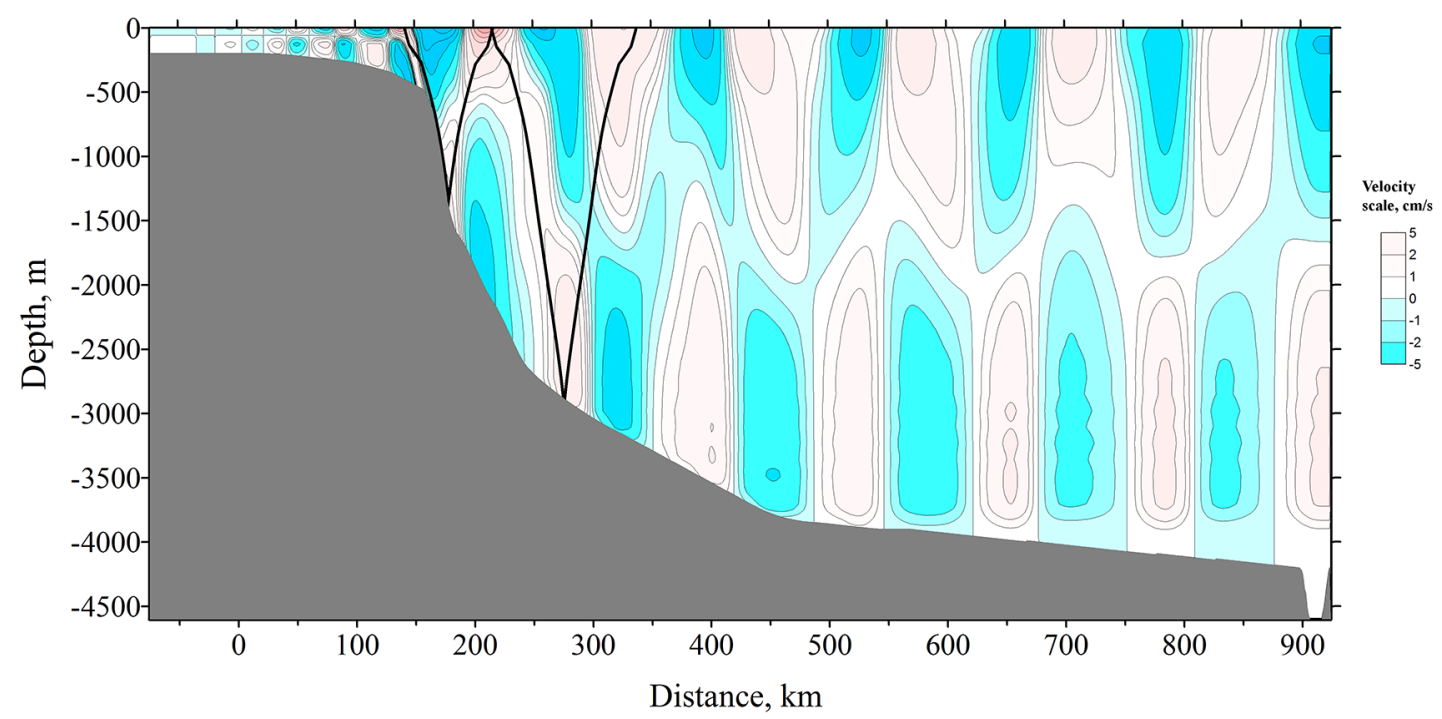

Fig. 4. Simulated velocity field over a section normal to the coast over the Santos Plateau after 10 tidal periods of calculation. Characteristic lines (beams) of internal tides are shown with black curves.

Beams of internal tides start at the continental slope. When they reach the surface and bottom the beams are reflected. Approximately at a distance of one wavelength the beam structure of internal tides turns to the model structure (Morozov, 2018).

\section{Energy decay with distance}

Mooring measurements on 9 moorings in a line from the continental slope of South America allowed us to analyze the decrease in the energy of internal tide in the course of the wave propagation. The estimates of the energy density of internal tide were calculated using the approach described in (Lozovatsky et al., 2003). The energy density of internal tides $\left(\mathrm{J} / \mathrm{m}^{3}\right)$ was plotted versus the distance normalized by the wavelength of the first mode of internal tides $(145 \mathrm{~km})$. The value of $145 \mathrm{~km}$ was selected similar to the previous estimates in various regions of the ocean to conserve uniformity. The energy decay was compared with the decay found previously in our work in the Indian Ocean. However, the absolute values of the internal tide energy radiated from the slope were smaller (Fig. 4). We think that this occurs because the measurements in the Indian Ocean were performed near the Mascarene Ridge, which is the region of the extreme internal tides.

The energy densities of internal tide $\left(E_{I T}\right)$ were averaged over the wave period according to Torgrimson and Hickey (1979), Holloway and Merrifield (1999), and Lozovatsky et al. (2003). In this research we used a band-pass filter to separate semidiurnal tidal components from the velocity and temperature time series. The band-pass filter was tuned to the central frequency $\mathrm{M}_{2}$ (period $12.4 \mathrm{~h}$ ). The density of the kinetic energy of the horizontal components of internal tide was determined as the sum of squared amplitudes of velocity. The total energy density of internal tide was calculated from the following relation: 


$$
E_{I T}(z)=0.25 \rho\left(\overline{u_{I T}^{2}(z)}+\overline{v_{I T}^{2}(z)}+N^{2}(z) \overline{\varsigma_{I T}^{2}(z)}\right)=E_{H}+E_{\zeta}
$$

Here, $u_{I T}, v_{I T}$ are the amplitudes of the velocity components of the semidiurnal internal tide, $\zeta_{I T}$ are the similar amplitudes of vertical displacements (Lozovatsky et al., 2003). Internal tide velocity components were calculated from the mooring data subtracting the barotropic tide velocities.

Horizontal velocities of the barotropic tide were calculated using the OTIS tidal inversion software based on the data of satellite altimetry (Egbert and Erofeeva, 2002). The energy density of internal tides was calculated from the time series 42 days long to exclude the spring-neap variability (14 days).

We normalized the distances by the scale equal to the wavelength of the first mode $\mathrm{L} / 145 \mathrm{~km}$. We analyzed the decay of internal tide energy density over the range of distance between the mooring located at the closest distance to the $500-\mathrm{m}$ isobath $(25 \mathrm{~km})$ and the most remote one $(888 \mathrm{~km})$. The instruments were set approximately at a depth of $900 \mathrm{~m}$. The energy decay is approximately $15 \%$ loss of energy over one wavelength.

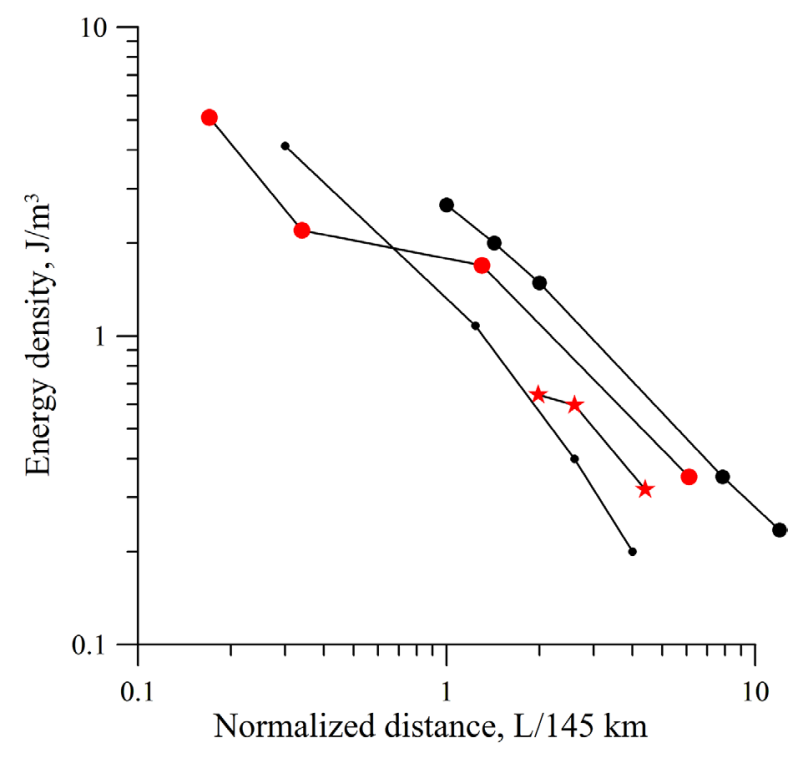

Fig. 5. Decay of internal tide energy $E_{I T}=E_{H}+E_{\zeta}$ of the semidiurnal internal tide with the distance from the continental slope. The distance from the slope is normalized by the wavelength of the first mode L/145 km. The measurement depth is approximately at $900 \mathrm{~m}$. Energy density from ACM 3 moorings is shown with red circles; energy density from ACM 12 moorings is shown with red stars; energy density from the moorings in the Indian Ocean (Mascarene Ridge) is shown with large black dots; model energy decay is shown with small black dots.

The decay of energy density is shown in Fig. 5. The energy density of internal tides decreased by a factor of 10 over a distance of $888 \mathrm{~km}$. This distance is approximately equal to 6 wavelengths. Hence, the energy losses are approximately $20 \%$ over one wavelength. 


\section{Е.Г. Морозов}

We compared the energy decay of the internal tide in the Santos Plateau region with the Mascarene region in the Indian Ocean. The graph of energy decay near the Mascarene Ridge is also shown in Fig. 5. The energy levels in both regions are different but the rate of energy decay is very similar to the one analyzed near the Mascarene Ridge.

We compared the decrease in the energy density found from the field data with the model estimates. The curve of model energy decay is also shown in Fig. 5. The amplitudes of internal tide decrease from the continental slope in the direction to the Vema Channel from $36 \mathrm{~m}$ to $15 \mathrm{~m}$. The model estimates decrease faster, which indicates that we did not take into account all energy sources in the model. The vertical displacements and horizontal velocities were processed using the same algorithm as the measured values.

\section{Acknowledgments}

This work was accomplished within the framework of the state assignment of FASO Russia (theme No. 0149-2018-0003 and supported by the Russian Foundation for Basic Research (grant no. 17-08-00085).

\section{References}

Egbert G.D. and Erofeeva S. Efficient inverse modeling of barotropic ocean tides. J. Atmos. Ocean Tech., 2002, Vol. 19, pp. 183-204.

Holloway P.E. and Merrifield M.A. Internal tide generation by seamounts, ridges, and islands. J. Geophys. Res., 1999, Vol. 104 (C11), pp. 25937-25951.

Lozovatsky I.D., Morozov E.G., and Fernando H.J.S. Spatial decay of energy density of tidal internal waves. J. Geophys. Res., 2003, Vol. 108 (C6), pp. 3201-3216.

Morozov E.G. Semidiurnal internal wave global field. Deep-Sea Res., 1995, Vol. 42 (1), pp. $135-148$.

Morozov E.G. and Vlasenko V.I. Extreme tidal internal waves near the Mascarene Ridge. J. Marine Sys., 1996, Vol. 9 (3-4), pp. 203-210.

Morozov E.G., Demidov A.N., and Tarakanov R.Yu. Transport of Antarctic waters in the deep channels of the Atlantic Ocean. Doklady Earth Sciences, 2008, Vol. 423 (8), pp. 1286-1289.

Morozov E.G. Oceanic Internal Tides, Observations, Modeling and Analysis. A Global View. Dordrecht: Springer, 2018, 316 p.

Pereira A.F. and Castro B.M. Internal tides in the Southwestern Atlantic off Brazil: observations and numerical modeling. J. Phys. Oceanogr., 2007, 37 (6), pp. 1512-1526.

Speer K.G. and Zenk W. The flow of Antarctic Bottom water into the Brazil Basin. J. Phys. Oceanogr., 1993, Vol. 23, pp. 2667-2682.

Torgrimson G.M. and Hikecy B.M. Barotropic and baroclinic tides over the continental slope and shelf off Oregon. J. Phys. Oceanogr., 1999, Vol. 9, pp. 945-961.

Vlasenko V., StashchukN., and Hutter K. Baroclinic Tides: Theoretical Modeling and Observational Evidence. Cambridge, Cambridge Univ. Press, 2005, 351 p.

WOD13 (2013) World Ocean Database 2013, Geographically Sorted Data. https://www.nodc.noaa.gov/OC5/WOD/datageo.html; last updated October 26, 2013; last accessed in October 2017. 


\title{
ВНУТРЕННИЙ ПРИЛИВ НА ПЛАТО САНТОС
}

\author{
Е.Г. Морозов
}

\author{
Институт океанологии им. П.П. Ширшова РАН, 117997, Москва, \\ Нахимовский проспект, д. 36, E-mail: egmorozov@mail.ru \\ Статья поступила в редакцию 02.02.2018, одобрена к печати 26.04.2018
}

\begin{abstract}
Мы анализируем внутренние приливы на Плато Сантос в Южной Атлантике. Исследование основано на измерениях температуры и течений на линии буев по нормали к побережью Южной Америки, в широтном диапазоне между $28^{\circ} \mathrm{S}$ и $31^{\circ} \mathrm{S}$. Буи были выставлены на расстояниях от 25 до 888 км (от 500 м изобаты) к юговостоку от континентального склона. Приборы были установлены на глубине 900 м. Численное моделирование выявило свойства внутренних приливов (амплитуды, длину волны и уменьшение энергии) вдоль линии их распространения от континентального склона. Амплитуды внутреннего прилива уменьшаются от континентального склона в направлении к каналу Вима от 36 м до 15 м. Плотности энергии приливных внутренних волн вычислялись из полусуточных приливных компонент временного ряда течений и температуры с учетом вертикальных градиентов температуры и частоты ВяйсяляБрента. Затухание энергии внутреннего прилива соответствует обратному степенному закону. Численное моделирование генерации и распространения внутренних приливов показывает, что вблизи континентального склона образуются лучи внутренних приливов. Затухание энергии по результатам численного моделирования соответствует данным измерений.
\end{abstract}

Ключевые слова: внутренний прилив, буи, плато Сантос, Бразильская котловина, численное моделирование, затухание энергии

\section{Литература}

Egbert G.D., Erofeeva S. Effici ent inverse modeling of barotropic ocean tides // J. Atmos. Ocean Tech. 2002. Vol. 19. P. 183-204

Holloway P.E., Merrifield M.A. Internal tide generation by seamounts, ridges, and islands // J. Geophys. Res. 1999. Vol. 104 (C11). P. 25,937-25,951.

Lozovatsky I.D., Morozov E.G., Fernando H.J.S. Spatial decay of energy density of tidal internal waves // J. Geophys. Res. 2003. Vol. 108 (C6). P. 3201-3216.

Morozov E.G. Semidiurnal internal wave global field // Deep-Sea Res. 1995. Vol. 42 (1). P. $135-148$.

Morozov E.G., Vlasenko V.I. Extreme tidal internal waves near the Mascarene Ridge // J. Marine Sys. 1996. Vol. 9 (3-4). P. 203-210.

Morozov E.G., Demidov A.N., Tarakanov R.Yu. Transport of Antarctic waters in the deep channels of the Atlantic Ocean // Doklady Earth Sciences. 2008. Vol. 423 (8). P. 1286-1289.

Morozov E.G. Oceanic Internal Tides, Observations, Modeling and Analysis. A Global View. Dordrecht: Springer, 2018. 316 p.

Pereira A.F., Castro B.M. Internal tides in the Southwestern Atlantic off Brazil: Observations and numerical modeling // J. Phys. Oceanogr. 2007. 37 (6). P. 1512-1526.

Speer K.G., Zenk W. The flow of Antarctic Bottom water into the Brazil Basin // J. Phys. Oceanogr. 1993. Vol. 23. P. 2667-2682.

Torgrimson G.M., Hikecy B.M. Barotropic and baroclinic tides over the continental slope and shelf off Oregon // J. Phys. Oceanogr. 1999. Vol. 9. P. 945-961.

Vlasenko V., Stashchuk N., Hutter K. Baroclinic Tides: Theoretical Modeling and Observational Evidence // Cambridge: Cambridge Univ. Press, 2005. 351 p.

WOD13 (2013) World Ocean Database 2013, Geographically Sorted Data, https://www.nodc.noaa.gov/OC5/WOD/datageo.html; last updated October 26, 2013; last accessed in October 2017. 